Рад примљен: 12. 7. 2017.

Рад прихваћен: 15. 2. 2018.

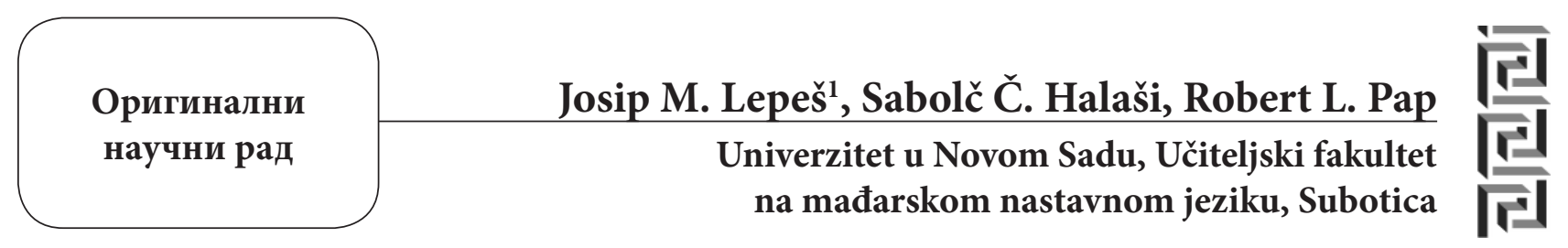

\title{
Značaj razvoja motoričkih sposobnosti kod učenika koji žive u nepovoljnim životnim uslovima
}

\begin{abstract}
Rezime: Istraživanjem smo tražili povezanost između školske uspešnosti dece koja žive u teškim životnim uslovima i razvijenosti motoričkih sposobnosti. U model smo uvrstili decu iz prvog razreda kako bismo bacili svetlost na nejednakost šansi koje se javljaju već prilikom početka školovanja među decom koja su izašla iz zabavišta. Cilj istraživanja je bio da se uporede i analiziraju razlike između telesne razvijenosti i motoričkih učinaka dece u teškim životnim uslovima i većinske dece, zatim da se ustanovi, ukoliko su razlike signifikantne, koliko je zaostajanje dece koja žive u nepovoljnim životnim uslovima. Podatke smo uzeli od petnaest učenika prvog razreda osnovne škole u Horgošu koje je psihološko-pedagoška stručna služba označila kao decu u nepovoljnom položaju. Merenja kontrolne grupe smo obavili na osamnaest većinskih učenika prvog razreda, koji su izabrani metodom slučajnog uzorka. Na osnovu rezultata istraživanja ukazali smo na značaj kvalitetne nastave fizičkog vaspitanja odgovarajuće učestalosti $i$ adekvatnog sadržaja kod dece koja žive u nepovoljnim životnim uslovima. Zaključili smo da razvijenost motoričkih sposobnosti doprinosi i optimalnom razvoju osnovnih kompetencija neophodnih za školsko učenje, kao i socijalnih kompetencija.
\end{abstract}

Ključne reči: motoričke sposobnosti, životni uslovi, telesni razvoj, fizičko vaspitanje, učenje.

Uvod

Nažalost, ima dece koja žive u nepovoljnim životnim uslovima i sa socijalnim i kulturno-obrazovnim hendikepima započinju školovanje u osnovnoj školi. Potiču iz siromašnih porodica, okruženi nezaposlenim odraslima i srodnicima, zarobljeni u mreži kontinuiranih, svakodnevnih konflikata, nesposobni da se iz nje izbave. Sociokulturno polje, koje utiče na njihove odnose u zajednici, već po sebi određuje i njihove potrebe. Krećući se duž svojih marginalnih vrednosti, često postupaju protivno sopstvenim interesima. Njihova neposredna okolina često ima negativan uticaj na njihove neodlučne pokušaje da se uzdignu. Životom u nepovoljnom društvenom

1 lepes@tippnet.rs Copyright (๑) 2018 by the authors, licensee Teacher Education Faculty University of Belgrade, SERBIA

This is an open access article distributed under the terms of the Creative Commons Attribution License (CC BY 4.0) (https://creativecommons.org/licenses/by/4.0/), which permits unrestricted use, distribution, and reproduction in any medium, provided the original paper is accurately cited. 
položaju intenzivira se stepen hendikepa usled zatvaranja društvene mobilnosti. Ovi problemi dolaze do višestrukog izražaja u slučaju mladih koji potiču iz siromašnih porodica, a imaju želju za daljim učenjem i usavršavanjem. Mobilizacijski kanal društva u Srbiji je i u sadašnje vreme ostao nepromenjen, a to se odnosi na nastavak školovanja. Na državnom nivou svake godine približno $85 \%$ mladih namerava da nastavi školovanje. Sledeću grupu sačinjavaju oni koji izostaju iz osnovnog obrazovanja. Iskustva pokazuju da od $15 \%$ do $17 \%$ mladih koji su se upisali u srednju školu ne uspeva da je završi. Prema tome, ako se sve to sabere, jedna trećina društva iz raznoraznih razloga ostaje slabo školovana, stručno nekvalifikovana, i to dovodi do problema u zapošljavanju, manjkavosti u pogledu prihoda, mobilnosti i napredovanja.

Svi ti momenti su upadljivi u krugu stanovništva u naseljima koja su dospela u ekonomski nepovoljan položaj, a jedno od takvih je i Horgoš. Valja posebno istaći da iz raznih razloga izvestan broj romske dece usled nedovoljne porodične pomoći, podsticaja i motivacije ne uspe da završi osnovnu školu. Ostali, koji je završe, takođe to čine uz česta spoticanja, stariji od ostalih, opterećeni konfliktima. Jedan deo svršenih đaka - poučeni svojim iskustvima - čak i ne pokušava da nastavi školovanje. Većina onih koji ipak prihvataju iskušenja ispadaju iz tog kruga zbog slabog uspeha u školi, doživljenih serija neuspeha i zbog uticaja sredine. Deca koja u sebi nose destimulativnu snagu porodične klime $\mathrm{i}$ iskustva diskriminacije u osnovnoj školi teško ispunjavaju očekivanja srednjih škola. Stoga, dete sa osrednjim kognitivnim sposobnostima, ali veštih ruku, takođe ostaje kod kuće. Međutim, uz ozbiljnu i odlučnu pomoć koja bi dalekosežno uzimala u obzir njihove interese i ono što je njima bitno imali bi šansu da postignu pozitivne rezultate. Niski stepen obrazovanosti se reprodukuje, čemu je višestruko nepovoljan društveni položaj i uzrok i posledica.

Zapadnoevropska istraživanja su potvrdila da su neki od determinantnih uzroka - koji su ujedno i posledice - niskog uspeha u školovanju loša socijalna sredina, nepodnošljivi stambeni uslovi i negativna porodična motivacija koja prati ove okolnosti. Dosadašnja istraživanja su se ispitivanjem efekata materijalnih činilaca koji uzrokuju pedagoški neuspeh bavila samo kada je bilo reči o naročito lošim prilikama (američka geta), koje su gotovo onemogućile bilo kakvo prilagođavanje. Novija istraživanja su, međutim, dokazala da situacija i ne mora da bude naročito ekstremna da bismo težinu materijalnih faktora mogli smatrati značajnom. Ograničavajući efekat oblika socijalizacije, različitih prema sloju kojem se pripada, još više pojačava škola kao društveni sistem koji reprodukuje socijalne karakteristike srednje klase. Sistem društvenih aspekata onih koji su u nepovoljnom društvenom položaju i njihovi procesi socijalizacije se ne vezuju za školu, za njene vrednosti, za njene norme učenja i postignute rezultate. Slojevi koji su u nepovoljnom društvenom položaju, nacionalne i etničke manjine, to jest ona supkultura iz koje dete potiče - najčešće je u suprotnosti sa ciljevima ustanove ili se, u najmanju ruku, odnosi ravnodušno prema njoj. Ona supkultura koja se fiksira tako što je podređena sopstvenoj fizičkoj i društvenoj sredini teško može da osnažuje individualno osećanje sigurnosti. Roditelji koji žive u takvim okolnostima ne shvataju da bi njihova deca mogla da se uzdignu makar samo za jedan stepen/ nivo više.

$\mathrm{Na}$ osnovu međunarodnih podataka dobro je poznata činjenica da deca iz porodica koje pripadaju osetljivim društvenim grupama - siromašni, neškolovani roditelji - počinju svoje školovanje sa vrlo ozbiljnim nedostacima (Hart \& Risley, 1995; Lee \& Burkam, 2002). Njihove kognitivne kompetencije u ranom detinjstvu često pokazuju znatno zaostajanje u odnosu na svoje vršnjake, koje mogu da nadoknađuju najčešće samo visoko kvalitetni, dugotrajniji, kompetentni i kompenzacioni programi za malu decu. U nedostatku ovih uravnotežujućih činilaca deca koja žive u nepovoljnim životnim uslovima u toku svog školovanja mogu nagomilati zaostajanja takvih razmera, za čije nadoknađivanje nije 
dovoljno čak ni dvanaest godina provedenih u javnom obrazovanju (Brooks \& Gunn, 2003; Rolnick \& Grunewald, 2003; Waiting Rarely Works, 2004; Heckman, 2006a; 2006b).

\section{Istraživanja o motoričkom razvoju}

Uopšteno govoreći, možemo reći da raspolažemo ogromnim unutrašnjim znanjem o svom kretanju, jednostavnim i složenim pokretima. Zbog toga je Gardner (Gardner, 1983) smatrao motoričku ili psihomotoričku sposobnost za jednu od najosnovnijih i najčešće korišćenih ljudskih kompetencija, za jednu od značajnih formi ljudske inteligencije, koju je registrovao kao telesno-kinestetičku inteligenciju. Međutim, vrlo lako možemo uvideti da je prilično teško da se svesnost dovede u vezu sa kretanjem, uprkos tome što većinu svojih pokreta učimo. Ali svoje pokrete obično vršimo bez svesne pažnje i zbog ovog nesvesnog prelaženja u naviku nisu nam se formirala precizna pojmovna sredstva za formulisanje obeležja pokreta, njegove strukture, tačnog načina njegovog izvršenja, što će reći da obuhvatanje pokreta u kognitivne jedinice predstavlja ozbiljnu poteškoću. $U$ vezi sa izričito nesvesnim karakterom ljudskog kretanja Viljem Džejms (James, 1980) već u XIX veku je postavio teoriju poznatu kao hipoteza lanca odgovora. Prema toj teoriji, kada se jedna radnja fiksira tako da, koristeći Džejmsov (James, 1890: 112) rečnik, postaje "habituelno“ - jedini impuls koji misaoni ili percepcijski centri odašilju izvršnim organima jeste inicijalni impuls, zapovest starta. Kada posle početnog impulsa sekvencija biva završena, krajnji rezultat dobija svesnu pažnju, ali se između dve tačke pažnje sekvencija odigrava bez svesnosti ili intervencije, to jest, kako se to obično kaže, pokret postaje automatski. Međutim, već je i Džejms (James, 1890: 116) skrenuo pažnju da i u ranoj fazi učenja sekvencije pokreta svesnost ima jak uticaj. Fits (Fitts, 1964) određuje tri determinantne faze motoričkog učenja: kognitivnu, asocijativnu i automatsku fazu. U kognitivnoj fazi onaj ko uči upoznaje osnove procesa i često upotrebljava verbalne elemente. Fits (Fitts, 1964) kao kognitivne osnove kretanja smatra svesno iskušavanje i/ili simboličku reprezentaciju kritičnih delova zadatka - ali je u krajnjoj instanci mišljenja da se jedina neporeciva karakteristika kognitivnog postupka sastoji u tome da je unutrašnja reprezentacija.

Kerol i Bandura (Caroll \& Bandura, 1982) istraživali su u eksperimentalnim uslovima vezu između dejstva demonstracije i kompleksnosti prostora kretanja tokom savladavanja jednog modela postupanja. Došli su do zaključka da u početnoj fazi učenja jednog kompleksnog niza kretanja vizuelni povratni signal nije poboljšao predavanje. Iz toga su zaključili da je vizuelna demonstracija korisna samo ako već postoji načelni model postupanja. Za njegovo formiranje potrebno je nekoliko proba vežbanja, stoga se samo učenje može izvesti jedino onda ako onaj ko uči raspolaže nekom od reprezentacija modelovanog događaja.

U svom novom eksperimentu Kerol i Bandura (Caroll \& Bandura, 1987: 385) postavili su hipotezu da se demonstracijom uspostavljena informacija kretanja može steći opažanjem glavnih obeležja kretanja i putem kognitivnih proba. Tokom učenja niz akcija se simboličkim kodiranjem pretvara u kognitivnu reprezentaciju i izvođenje radnje usmerava već kognitivna reprezentacija. Povodom učenja jednog modela kretanja kopiranjem zaključili su da je opažanje jednovremeno sa izvršenjem pomoglo reprodukciju modela postupanja samo ako je već formirana njegova adekvatna kognitivna reprezentacija. Po sticanju tačne kognitivne reprezentacije subjekti eksperimenta su bili u stanju da po sećanju reprodukuju prikazan niz postupaka jednako tačno kao tokom izvršenja istovremenog sa prikazivanjem. Na osnovu svog istraživanja i onoga što je tome prethodilo, Kerol i Bandura (Caroll \& Bandura, 1987: 379) odlučno su tvrdili da kognicija igra važnu ulogu u učenju kretanja.

Tokom istraživanja kognitivnih faktora koji utiču na motoričku sposobnost brojni istraživači su 
eksperimentisali sa dejstvom mentalnog vežbanja na kompetenciju kretanja.

Usmereno mentalno vežbanje, pruženo tokom učenja pokretnog zadatka, poboljšalo je, kako učenje sekvencije, tako brzinu i kvalitet izvršenja, i dokazalo se kao efikasnije od vežbanja zasnovanog na oponašanju. Dejstvo usmerenog mentalnog vežbanja je bilo najpotentnije, kada je pruženo pre upoznavanja sa zadatkom.

Nađ (Nagy, 2004) veruje da je osnova teorijskih saznanja stečenih o kretanjima - $\mathrm{u}$ formi pojma - reč. Nađ (Nagy, 1972: 210) skreće pažnju na to da za vreme podučavanja kretanju vrednost uputstava je utoliko veća ukoliko je vežba kompleksnija i teža. Učenje kretanja potpomognuto verbalizacijom može da bude uspešnije zato što direktive primenjene stručnim jezikom omogućavaju učenicima da svoju pažnju usredsrede samo na suštinu.

Maksin (Makszin, 1994: 113) u vezi sa učenjem kretanja istakao je da pojedinac treba da bude sposoban da rečima izrazi svoja zapažanja pokreta, zato valja sačiniti nedvosmislen verbalni aparat koji odgovara kriterijumima kreiranja pojmova o kretanju.

\section{Faktori koji nepovoljno utiču na razvoj kretanja kod učenika koji žive u nepovoljnim životnim uslovima}

Uspešnost početka pohađanja škole ima značajnu ulogu u tome dokle je dete stiglo u usvajanju onih kompetencija na koje se nadograđuje učenje u školi. Dokle je stiglo u razvoju maternjeg jezika? Poseduje li elementaran pojam brojeva?

Iz ranijih istraživanja znamo da je razvoj ovih sposobnosti nešto što iziskuje vreme, da je to proces koji traje godinama. Prilikom stupanja u školu među decom se mogu ustanoviti višegodišnje razlike u razvoju (Nagy, 1980; Nagy et al., 2004b). Kada započinju školovanje, kod jednog dela učenika razvijenost sposobnosti odgovara tek prosečnom ni- vou četvorogodišnjaka, odnosno petogodišnjaka. Ovu zaostalost škola ne može da nadoknadi. Značajan deo polaznika sa hendikepom definitivno zaostaje za svojim vršnjacima tokom prvih školskih godina. Uspešnost početka školovanja može da odredi budućnost deteta za čitav život. Razlika među decom samo raste tokom školskih godina.

Neizostavan uslov za uspešan početak školovanja je da učenje u školi pruži detetu radost. Ako su prva školska iskustva praćena neuspesima, može da dođe do oštećenja motiva za učenje. Ako se to dogodi, dete neće biti podstaknuto da u školsko učenje uloži energiju i vreme, a to u samim temeljima sprečava razvoj (Józsa, 2007a).

U poslednje vreme je u odnosu na vaspitanje i pedagogiju porastao zahtev u pogledu delotvornijeg i uspešnijeg formiranja čoveka. Babošik ističe da je „najopštiji zadatak pedagogije socijalizacija pojedinca, to jest njegovo pripremanje za obavljanje društvenih funkcija i zadataka visokog nivoa" (Bábosik, 1982: 156).

Sadržaj fizičkog vaspitanja sam po sebi treba da ima dejstvo razvijanja ličnosti, budući da se čovek može interpretirati samo u svom psihosomatskom biću, ali se uistinu može smatrati funkcionalnim delom procesa vaspitanja ako se razvijaju i kognitivna i afektivna sfera, u prvom redu karakter, a kroz to se formiraju dragoceni običaji (Rókusfalvi, 1980: 276). Prema Babošiku, „među formama ponašanja koja služe zdravom opstanku pre svega treba istaći kretanje“ (Bábosik, 2004: 29).

Proteklih decenija se na području vaspitanja nakon početnog uspona mogao zapaziti zastoj, zbog čega se povećava vrednost onih oblasti u kojima se odgoj može odvijati intenzivnije i delotvornije. Takva oblast može da bude telesni odgoj. Pomoću fizičkog vaspitanja kod dece razvijamo moralne, voljne osobine, razvijamo praktične kompetencije i pripremamo ih za zdrav način života, kao i na ispunjavanje svojih obaveza u sferi rada. Stekavši pozitivne doživljaje tokom kretanja, otvara se mogućnost za reprodukciju telesnih, duhovnih, osećajnih energija 
(Rókusfalvi, 1980). Između školske spreme roditelja i odnosa deteta prema školi i fizičkoj kulturi može da se pronađe veza. Većina se miri sa svojom sudbinom i nije motivisana za školske aktivnosti. U nedostatku roditeljske podrške dete je upućeno na sebe, pa tako nastavnici bivaju opterećeni teškim zadatkom.

Idući pod ruku sa zdravim načinom života, fizička aktivnost deluje na kvalitet života, a to je povezano sa zdravljem (Vuillemin et al., 2005). Sport može da predstavlja mogućnost da se društveno inferiorni slojevi uključe u društvo (Borkovits, 2013a; Egressy, 2005). Materijalni položaj definiše način života pojedinaca, socijalna pozadina određuje odnos prema zdravlju (Borkovits, 2013a; 2013b). Rekreativnim programom kretanja i fizičkom aktivnošću povezanom sa zdravljem neravnopravnosti mogu da budu izjednačene (Borkovits, 2013c; Borkovits, 2013d).

\section{Uticaj poremećaja koordinacije pokreta na smetnje u učenju}

Učenje je proces koji se razlikuje od pojedinca do pojedinca i na čiju uspešnost uticaj imaju mnogobrojni činioci. U poslednje vreme se sve veća pažnja usmerava na onaj krug pojava koji stručna literatura navodi pod nazivom „smetnje u učenju“. Postalo je očigledno da uzrok neodgovarajućeg učinka đaka ne moraju da budu samo nemarnost i lenjost; na to mogu da utiču individualna psiha, pedagog koji se bavi učenikom, primenjene edukativno-razvojne strategije, školski i porodični ambijent.

Sporan je i naziv skupa simptoma, njegovo poreklo i karakteristike. I u stručnoj literaturi mogu da se nađu sinonimi: možemo da se sretnemo sa nazivima smetnja u učenju, poremećaj učenja, teškoća u učenju (u engleskoj stručnoj literaturi: learning disability, learning disorder, developmental learning disability). Sam izraz - smetnja u učenju - pojavio se tek nedavno u stručnoj literaturi (Gyarmathy \& Telegdi, 1995). Izraz learning disability prvi je upo- trebio Semjuel Kirk (Samuel Kirk), a opšteprihvaćen postao je na jednoj konferenciji koja se bavila decom koja su preživela povrede mozga i bila suočena sa perceptivnim smetnjama. Po Kirkovoj definiciji, smetnja u učenju je „takvo zaostajanje, poremećaj ili zakasneli razvoj u procesima govora, čitanja, pisanja, računanja ili drugim školskim predmetima, koje uzrokuje psihološki hendikep izazvan mogućom moždanom disfunkcijom i/ili emocionalnim smetnjama odnosno smetnjama u ponašanju. Ne izazivaju ga mentalna defektnost, manjkavost čulnih organa ili kulturni ili obrazovni faktori“ (Kirk \& Bateman, 1962: 73-78). Naglašava se povezanost između smetnji u učenju i ponašanju u školi sa povređenim psihološkim tokovima. Ovaj opis je u suštini ostao osnova svake dalje definicije. Istraživači su smetnje u učenju pokušavali da grupišu na osnovu skupova simptoma. Ispitivanje dece predškolske dobi može da signalizira kasnije probleme, koji će da otežavaju učenje u školi: smetnje na području percepcije, smetnje u govornim sposobnostima i smetnje u pamćenju, nedostaci koji dotiču memoriju, lateralitet, neodgovarajuće funkcionisanje orijentisanja, smetnje u koordinaciji pokreta i smetnje pri finalnom kretanju. Uz ovo idu problemi vezani za ponašanje: poremećaji pažnje, hiperaktivnost. Ovim kompetencijama, sposobnostima upravlja centralni nervni sistem. Na neadekvatno sazrevanje centralnog nervnog sistema pažnju skreću smetnje koje se javljaju u razvitku kretanja. Disfunkcija centralnog nervnog sistema kasnije dovodi do takvih posledica kao što su teškoće na polju pažnje, pamćenja, razmišljanja, neodgovarajuća koordinacija, zaostajanje u socijalnim kompetencijama i emocionalnoj zrelosti. Prema tvrdnjama Baloga i Tota (Balogh \& Tóth, 1998), razlikujemo četiri tipa uspešnosti procesa učenja:

- u središtu verbalnog učenja stoji razumevanje, obrada tekstova, a osnovni mehanizmi su ovde razumevanje, analiza, pamćenje;

- kod senzornog (perceptualnog) učenja razvija se percipiranje, opažanje; 
- proces motoričkog učenja ima značaja kod psihomotoričkih radnji, što dobija ulogu kod učenja pisanja, čitanja, crtanja;

- socijalno učenje je od fundamentalnog značaja u učenju društvenih uloga, interpersonalnih veza i stavova.

\section{Značaj ranog prepoznavanja smetnji u razvoju}

Istraživanja ukazuju na to da znatna zaostalost odojčeta, mališana u razvitku kretanja zbog motoričkih problema u većini slučajeva nagoveštava mogućnost budućih teškoća u učenju koje se javljaju u školi. Smetnje u razvoju kretanja obično dotiču neku od motoričkih funkcija, a ove imaju povratno dejstvo i na razvoj govora, odnosno jezičku sposobnost. Značaj ima svaka faza razvitka kretanja; pažnju izaziva ako iz ovog razvoja izostane, na primer, faza puzanja. Različite motoričke funkcije, prirodni oblici kretanja, složena kretanje pokazuju tesnu vezu sa kasnijim odgovarajućim obavljanjem zadataka čitanja, crtanja. Zbog toga naglasak treba staviti na rano razvijanje, na jačanje nervnih puteva, što omogućava izvršavanje pokretnih zadataka.

Stručnjaci su pre više od jedne decenije osim na smetnje u učenju ukazali i na psihosocijalne smetnje, koje se javljaju kao deficit druženja, odnosno na poremećaje pažnje - hiperaktivnost. To je potvrđeno u onim istraživanjima u kojima se potvrdila hipoteza da simptomi idu zajedno i pokazalo prisustvo socijalnih problema kod dece koja se bore sa smetnjama u koordinaciji pokreta. Oslanjajući se na rezultate, može se pretpostaviti da smanjenjem motoričkih problema i elimisanjem smetnji u učenju nastalih drugim uzrocima postaje moguća i prevencija psihosocijalnih problema, koji se javljaju zbog neadekvatnih školskih učinaka deteta. Motoričke funkcije mogu da se poboljšavaju nadraživanjem nervnih puteva; rezultati koji se javljaju na polju pisanja, čitanja, računanja i pozitivni doživljaji koji ih prate deluju i na intenziviranje aktivnosti i pažnje, budući da prestaje bezvoljnost koja nastu- pa zbog neuspešnosti, a što je dovelo do nezainteresovanosti prema školskom radu. Po našem mišljenju, sve to skreće pažnju stručnjaka koji se bave decom na to koliko je važno rano prepoznavanje uzroka koji izazivaju smetnje u učenju, otklanjanje uzroka ili njihovo ublažavanje posredstvom razvijanja, a posle postizanja rezultata i kasnije i pažljivo praćenje, naročito u slučaju učenika u nepovoljnim životnim uslovima.

Razvijanje znanja i sposobnosti igra središnju ulogu u školskoj nastavi. Srećemo se sa brojnim modelima za definisanje odnosa znanja i sposobnosti, te odnosa znanja i kompetencija. Na osnovu primenjenih i fundamentalnih istraživanja, teorijskih radova, s vremena na vreme se menja pojam znanja i sposobnosti. „U vezi sa razvojem i razvijanjem sposobnosti najznačajnija promena u gledištima se možda ogleda u tome, da se danas sposobnosti više ne smatraju za suprotni pol ili alternativu materijalnog znanja, već kao sredstvo koje igra centralnu ulogu u sticanju, organizovanju i korišćenju znanja“ (Csapó, 2001: 270).

\section{Veza kretanja i intelektualnog razvoja}

Od Pijažea pa naovamo je opštepoznato da su kretanje i intelektualni razvoj međusobno povezani. Prema kognitivnoj teoriji razvoja švajcarskog psihologa, ako se prve dve godine života - tzv. senzomotorni period - odigraju u sredini na odgovarajući način bogatoj nadražajima i u mnogo sopstvenih aktivnosti, od strane roditelja podržavanih, onda se na ovde stečene osnove mogu harmonično nadograditi konkretne radnje, a posle toga i hijerarhijski manifestovane etape apstraktnog mišljenja.

Shodno toj teoriji, za uspešan učinak u školi zaista dobre izglede imaju ona deca (što pretpostavlja efikasno integrisane funkcije na višem nivou nervnog sistema / moždane kore) kod kojih su se pod zajedničkim dejstvom unutrašnjeg sazrevanja i spoljnih nadražaja sredine na vreme integrisali refleksi dojenčadi i elementarni modeli kretanja, po- 
tom su kontinuirano i u dovoljnoj meri bili izloženi vizuelnim, akustičkim, taktilnim i vestibularnim nadražajima odgovarajuće kakvoće za dalje procese sazrevanja njihovog nervnog sistema, što velikim delom znači otkrivačko, reaktivno i interaktivno kretanje u raznovrsnim mobilnim situacijama.

Zaostajanje u sazrevanju nervnog sistema, što se smatra jednim od uzroka školske nedozrelosti, odnosno poremećaji senzorne integracije mogu se desiti čak i onda ako je jedno dete rođeno sa zdravim nervnim sistemom, ali je u toliko važnim ranim godinama bilo izloženo manjoj količini nadražaja sredine ili ako je imalo oskudne mogućnosti kretanja. Naime, genetički programirano sazrevanje se ostvaruje samo u odgovarajućim uslovima sredine, u nadražajno siromašnoj/ograničavajućoj sredini sazrevanje struktura nervnog sistema biva usporeno, delom može da izostane, ne formiraju se veze između pojedinih oblasti, odnosno funkcionisanje već formiranih veza postaje nesigurno i zavisno od trenutnih okolnosti, štaviše, može da se desi i to da nastanu defektni funkcionalni mehanizmi.

Istraživači u okviru druge naučne grane, koja se bavi ljudskim kretanjima, povezujući eksperimentalnu psihologiju sa fizičkim vaspitanjem i kretanjima sa aspekta nervnog sistema, fizičkim i bihevioralnim aspektima, dakle, istraživači humane kineziologije, potvrdili su da planiranje kretanja i razmišljanje počivaju na analognim funkionisanjima nervnog sistema, budući da u obama slučajevima istovetni element sačinjava rešenje problema, za šta je potrebna brza i tačna obrada pristiglih informacija. Kod ovih funkcija to je podjednako osnovni uslov i pravilno funkcionisanje procesa vezanih za pažnju i pamćenje.

Svako ispoljavanje $u$ ponašanju, pa tako $i$ izvođenje dobro koordinisanih kretanja, pažnja, samodisciplina, kao i kognitivne i intelektualne funkcije reprezentuju procese koji se odvijaju u različitim strukturama nervnog sistema. Uzrok bilo kakvog odstupajućeg funkcionisanja može, dakle, da bude regulatorna nezrelost supkortikalnih struktu- ra i manjkavost senzornog integracijskog funkcionisanja.

Da bismo mogli da učimo, naš organizam treba da obavi jednu veoma fino usklađenu aktivnost prijema/prerade nadražaja i stvaranja produkta.

Ako određena parcijalna područja deluju sporije ili pogrešno, ako su nezrela, neusklađena sa ostalima, ona sprečavaju proces učenja. U brojnim slučajevima, kada su u razvojnom toku deteta izostale faze ili su sačinile pogrešan otisak u mozgu, tada ne postoje osnove za organizovane kognitivne funkcije na višem stepenu. Svaki nam proces učenja kreće sa nekom čulnom, aktivnom, iskustvenom osnovom, posle toga se javlja na misaonoj, apstraktnoj, pojmovnoj ravni.

Prvih sedam godina našeg života možemo da nazovemo i senzomotornom razvojnom fazom. Uređeno sklapanje percepcija izaziva u mozgu zadovoljstvo velikih razmera, naročito onda ako smo sposobni i za adaptivni odgovor. Čovek je predodređen da uživa u onim stvarima koje potpomažu razvitak njegovog mozga, stoga deca žele da se kreću, jer im to donosi senzomotoričku integraciju.

Slabije funkcionisanje jednog područja obično još nema za posledicu problem sa učenjem, jer nam mozak kompenzuje nedostatke. Ali je, s druge strane, veoma važno da prilikom polaska u školu parcijalne sposobnosti deteta, a u interesu uspešnog učenja, funkcionišu dobro: sređenost krupnih kretanja, ravnoteža, elastičnost, precizna fina motorika (ruka i usna), taktilno-kinestetički sistem, formirana dominacija (ruka-oko-noga-uvo), pravilna telesna šema, nezavisnost ekstremiteta (ruka-ruka, noga-noga, ruka-noga, prsti), opšta orijentacija, prostorna orijentacija (u prostoru, ravni), vremenska orijentacija, saradnja ukrštenih kanala, vizuelno opažanje i memorija, serijalne kompetencije (motoričke, akustičke, vizuelne), osećaj za ritam; kao i koordinacija oko-ruka, govorna sposobnost (artikulacija), opažanje, leksički fond, gramatika, razumevanje teksta i produkcija teksta, pažnja, svest o zadatku, pridržavanje zadatka, razmišljanje (analiza-sin- 
teza; figura-pozadina, konstantnost oblika i količine, upoređivanje, uopštavanje), razmišljanje koje rešava problem, socijalizacija, podnošenje neuspeha, kontrola ponašanja. Nabrajanje ne prati redosled važnosti, više se kreće od osnova ka višem stepenu organizovanih aktivnosti. Ako pogledamo, vidimo jednu vrlo složenu i slojevitu listu. U sebi sadrži bezbroj mogućnosti spoticanja budući da to nisu samostalno funkcionišuće jedinice, nego međusobno kompleksno isprepleteni sistemi.

\section{Uloga školskog fizičkog vaspitanja u razvoju učenika koji žive u nepovoljnim životnim uslovima}

Jedan od najznačajnijih zadataka je razvijanje sposobnosti, što omogućava da se iz datog stanja ličnosti razviju funkcionalne i korisne kompetencije. Bez razvijanja sposobnosti ostaju u dremljivom, latentnom stanju i, ako ostanu takve, neće da služe na dobrobit ni pojedinca ni društva. Međutim, među decom istog uzrasta mogu da postoje značajne razlike u razvoju i nadoknađivanje zaostatka može da iziskuje čak i više godina. Ispitujući u vremenskom kontekstu odstupanja unutar starosnih dobi, možemo da zapazimo da ova odstupanja rastu. Široko je rasprostranjeno mišljenje da razvoj pokazuje linearni rast, to jest da je razvijenost sposobnosti srazmerna životnoj dobi ili, u najmanju ruku, da je razvoj do koga je došlo tokom jednog datog perioda proporcionalan vremenu koje je proteklo. Prvobitna definicija kvocijenta inteligencije je takođe bila zasnovana na ovom shvatanju (mentalni uzrast podeljen sa kalendarskim uzrastom). Shodno tome, razlike među pojedincima proističu iz nejednakog, ali (s tačke gledišta datog učenika) konstantnog tempa razvoja.

Povodom procesa koji iskrsavaju u pozadini smetnji u učenju dr Katalin Balog Porkolabova (Porkolábné Balogh, 1992) rešenje vidi u razvijanju šeme kretanja, percepcije, tela i verbalnosti. Do kraja predškolskog uzrasta osnovno je poznavanje telesne šeme i orijentacije u prostoru. U normalnom slučaju te dve sposobnosti se razvijaju istovremeno, dete zna gde mu je pozicija u prostoru, poznaje položaj sopstvenog tela, ume da proceni daljine. U slučaju da postoji smetnja u telesnoj šemi, dete ne razume šta znači ispod, iznad, levo, desno. A bez tih saznanja ne ume da sledi uputstva pedagoga i da valjano obavi svoj zadatak. Zbog toga je važno da se u školu upišu samo ona deca koja su već sposobna da odgovore školskim zahtevima.

Do dobi od tri godine tokom razvoja dolazi do razdvajanja dotle neodvojivih perceptivnih i motoričkih funkcija i vodeću ulogu preuzima vid. Razliku među vizuelnim funkcijama pravimo po tome da li je reč o opažanju figure, prostora i oblika ili o poimanju boje. Viđenje figure (shvatanje pripadajućih delova kao jedinstvene celine, geštalt-viđenje) $\mathrm{u}$ početku je globalan način viđenja, dete još nije u stanju da prepozna parcijalne elemente, jer nema potrebnog sklada između vizuelnih i motoričkih funkcija. Kod dece od četiri do pet godina shvatanje figure je analitično, sada već raspoznaju pojedinačne strukturne elemente, ali ih zahvataju izolovano, bez njihove povezanosti sa celinom. Prepoznavanje povezanosti celine i delova, što je osnovni kriterijum učenja pisanja i čitanja, formira se do dobi od šest do sedam godina. Opažanje oblika (forma, ugao gledanja, površina, veličina) pokazuje u početku sličan razvojni tok: u početku dete uspeva samo upoređenjem dva elementa, do svojih pet-šest godina, da razmesti sve više predmeta prema veličini, boji i obliku. Stabilizacija odslikavanja zapažanja prostora i prostornih pravaca određena je formiranjem pravilnog razvoja kretanja i svesnosti telesne šeme.

Kvalitet opažanja prostora igra determinantnu ulogu u učenju čitanja. Iza grešaka u raspoznavanju slova (b-d, d-g, p-g, b-g i tako dalje) krije se sposobnost prepoznavanja i razlikovanja prostornih pravaca, odnosno nerazvijenost te sposobnosti. Verbalno osvešćavanje ima bitnu ulogu i u percepciji prostora. Svesnost telesne šeme je osnova formiranja ja-slike i razvijanja ja-svesti. Smetnje u telesnoj šemi mogu da dovedu do ometenog ja-razvitka 
i imaju određujući značaj u formiranju samovrednovanja i kompetencije. Motorički razvitak, razvoj ovladavanja telom protiče u zavisnosti od neuromuskularnih procesa sazrevanja. Među elementarne motoričke zadatke spada držanje tela, balansiranje, siguran hod. Nakon što je osnovno kretanje naučeno, u dobi od tri do šest godina veći zamah dobija razvitak fine motorike, od koje fundamentalno zavisi razvijenost mišića šake, razvijenost mišića prstiju, koji velikim delom određuju formiranje sposobnosti crtanja i pisanja. Forme kretanja koje iziskuju koordinaciju na relaciji oko-ruka, oko-noga postaju finije (hodanje na vrhovima prstiju, hodanje po stepenicama bez hvatanja za nešto).

Pri normalnom razvoju diferencijacija i integracija pomenutih perceptivnih funkcija odvijaju se istovremeno u dobi između tri i šest godina. Do šeste godine života formiran savršen perceptivni aparat predstavlja conditio sine qua non spoznaje na pojmovnom nivou. Ako nešto sprečava ili ometa ovaj rani proces učenja i do kraja perioda razvijenost i međusobna uređenost senzornih i motoričkih sistema nije zadovoljavajuća, onda dolazi do jedne specijalne smetnje u učenju gde dete, čak ni u posedu zdravih čulnih organa i normalnog - u nekim slučajevima čak i visokog - nivoa inteligencije, nije u stanju da nauči osnovne kulturne tehnike.

Prilikom ispitivanja uzroka poteškoća u učenju rođeno je više perceptualnih i perceptua-motoričkih teorija. Frostig, Horne (Frostig \& Horne, 1964) i Kephart (Kephart, 1966) objašnjavaju teškoće u učenju poremećajima čulnih organa. Nedostatak međusobne uklopljenosti raznih funkcija, nedovoljna integrisanost perceptivnih i motoričkih funkcija mogu da se, prema njihovoj pretpostavci, svedu na nedovoljnost ranih iskustava u učenju. Ovu decu karakteriše manjkava telesna šema i nesigurnost u orijentisanju, a budući da motorički odgovori dati na netačne perceptivne nadražaje nisu uspešni, ne podstiču na dalje motoričke odgovore, dok ta činjenica, sa svoje strane, postaje prepreka za formiranje finije koordinacije. Upućujući na jedan od mogućih načina korekcije, Kephart (Kephart, 1966) naglašava da se na percepciju može znatno uticati kroz razvijanje motoričkih sposobnosti.

U interesu umanjenja smetnji u učenju više istraživača rešenje vidi u razvijanju kretanja, percepcije, telesne šeme i u verbalnom razvijanju. $U$ slučaju dece koja žive u nepovoljnim životnim uslovima izričito je važno prepoznati faktore koji sprečavaju učenje i kontinuiranom aktivnošću smanjiti hendikepe proistekle iz nerazvijenosti motoričkih sposobnosti.

\section{Metodološki pristup}

Cilj istraživanja je bio da se uporede i analiziraju razlike u telesnoj razvijenosti i motoričkim učincima dece koja žive u nepovoljnim životnim uslovima i većinske dece koja žive u povoljnim životnim uslovima, zatim da se ustanovi, ukoliko su razlike signifikantne, koliko je zaostajanje dece koja žive u nepovoljnim životnim uslovima. Uzorak su činili učenici prvog razreda osnovne škole u Horgošu koje je psihološko-pedagoška stručna služba označila kao decu u nepovoljnom položaju. Merenja kontrolne grupe smo obavili sa učenicima prvog razreda koji su izabrani metodom slučajnog uzorka.

Antropometrijske karakteristike: visina, telesna masa i kožni nabor nadlaktice izmerene su kaliperom, kao i kožni nabor lopatice i kožni nabor trbuha. Procenom relativnog sadržaja masnog tkiva (podatak telesne mase izražen u postocima), kao i stanja uhranjenosti izračunali smo i indeks telesne mase (ITM) uz pomoć In Body 230 aparata koji utvrđuje sastav tela. Radi utvrđivanja kondicionalnih i koordinacijskih sposobnosti primenili smo motoričke testove u odgovarajućoj dobnoj grupi koja se javlja u uzorku:

- Brzina (trčanje na 20m, dodir ploče);

- Gipkost (pretklon trupa napred sedeći raznožno); 
- Ravnoteža (dinamička, statička ravnoteža sa otvorenim očima, statička ravnoteža sa zatvorenim očima);

- Snaga (skok iz mesta, izdržaj u zgibu, pregib trupom);

- Brzo reagovanje (trčanje osmice uz savijanje trupa);

- Koordinacija (klizeće koračanje, bacanje $i$ hvatanje lopte, vođenje lopte u mestu);

- Osećaj za ritam (trčanje sa promenom ritma).

Za analizu podataka koristili smo statistički program SPSS 20.0. U svom radu smo u svrhu prikazivanja antropometrijskih pokazatelja grupa podeljenih na osnovu socijalnog položaja, motoričkih kompetencija i veštine baratanja loptom primenili deskriptivnu statistiku, čime smo iskazali prosek, standardnu devijaciju grupa po varijantama, dok smo radi otkrivanja razlika među grupama (nepovoljnog položaja i normalnih sposobnosti) kod svake promenljive koristili t-test i na kraju smo analizom faktora (Varimax rotacija) uspeli da izdvojimo pet faktora čije dejstvo smo definisali analizom regresije za područja izmerena DIFER testom (test za utvrđivanje zrelosti za polazak u školu).

Budući da su razlike u prosecima u oblasti ispitane životne dobi evidentne i u grupi učenika koji žive u nepovoljnim uslovima i u kontrolnom uzorku (radi se o humanobiološkim evidencijama i biološkim evidencijama pod opterećenjem), u ovoj analizi smo se bavili samo t-testom i razlikama karakterističnih srednjih vrednosti ispitivane i kontrolne grupe. Maksimum slučajne greške u slučaju svake merene i računate promenljive odredili smo (saglasno opšteprihvaćenim konvencijama na stručnom polju) u visini manjoj od $5 \%$.

\section{Rezultati istraživanja}

Ovim istraživanjem smo dokazali da kod dece iz porodica iz osetljive socijalne grupe značaj- no i dosledno zaostaju prosek telesne visine i brzina rasta u odnosu na decu odgojenu u većinskim porodicama. Saglasno sa onim što smo ovde predstavili, i u ovom uzorku niži rast je bio povezan sa znatno većim indeksom telesne mase i relativnim sadržajem telesne masnoće, te sa merljivo slabijim fizičkim učinkom (kardiorespiratornom izdržljivošću). U interesu tačnije interpretacije takođe je potrebno da se naglasi da prosečan socioekonomski status uzorka korišćenog kao kontrolna grupa (ona koja ne potiče iz društveno osetljive sredine) takođe nije dobar, odnosno da u Horgošu uočljivo zaostaje za prosekom u Srbiji.

Iz deskriptivne statistike se može utvrditi da su većinski učenici postizali bolje rezultate od učenika koji žive u nepovoljnim životnim uslovima, a to je i statistički signifikantno kod promenljivih: $20 m$ trčanje $(\mathrm{t}=2,622 ; \mathrm{p}=0,014)$, staza sa preponama natraške $(\mathrm{t}=3,139 ; \mathrm{p}=0,004)$, dodir ploče $(\mathrm{t}=-3,652 ; \mathrm{p}=0,001)$, pretklon trupom sedeći raznožno $(\mathrm{t}=-3,905 ; \mathrm{p}=0,000)$, pregib trupom $(\mathrm{t}=-2,618$; $\mathrm{p}=0,014)$, statička ravnoteža sa otvorenim očima $(\mathrm{t}=-$ 2,732; $\mathrm{p}=0,010 ;)$, trčanje u grupi od osam $(\mathrm{t}=3,115$; $\mathrm{p}=0,007)$, klizajući korak $(\mathrm{t}=3,368 ; \mathrm{p}=0,002)$ i vođenje lopte u mestu $(\mathrm{t}=-2,272 ; \mathrm{p}=0,030)$.

Iz tabele 1. se jasno vidi da su se javile signifikantne razlike između kondicionalnih $i$ koordinacijskih sposobnosti učenika koji žive u nepovoljnim životnim uslovima i većinskih učenika. U slučaju svake signifikantne razlike slabije rezultate su postizali učenici u nepovoljnim životnim uslovima. To je posebno važno ako znamo da pokazatelji razvijenosti kondicionalnih i koordinacijskih sposobnosti vrše snažan uticaj na nivo sposobnosti učenja. Zaostajanje u kondicionalnim pokazateljima koje se javlja kod dece u teškim životnim uslovima upućuje na to da ova deca postepeno zaostaju u razvoju i time se smanjuje njihova radna sposobnost. Jasno se može primetiti da brzina (trčanje na 20 metara), gipkost (pretklon u sedećem položaju raznožno), snaga (pregib trupom) kao osnovne kompetencije pokazuju veće signifikantno zaostajanje kod dece u nepovolj- 
Josip M. Lepeš, Sabolč Č. Halaši, Robert L. Pap

Tabela 1. Motoričke sposobnosti učenika u nepovoljnim životnim uslovima i većinske dece.

\begin{tabular}{|c|c|c|c|c|c|c|}
\hline Promenljive & $\begin{array}{c}\text { Nova } \\
\text { raspodela } \\
\text { grupa }\end{array}$ & $\mathrm{N}$ & Prosek & $\begin{array}{c}\text { Standardna } \\
\text { devijacija }\end{array}$ & $\mathrm{t}$ & $\mathrm{p}$ \\
\hline \multirow{2}{*}{ visina } & 1 & 15 & 118,9600 & 6,06251 & \multirow{2}{*}{$-2,625$} & \multirow{2}{*}{,013 } \\
\hline & 2 & 18 & 124,1889 & 5,37903 & & \\
\hline \multirow{2}{*}{ telesna masa } & 1 & 15 & 23,113 & 5,5404 & \multirow{2}{*}{,- 739} & \multirow{2}{*}{,465 } \\
\hline & 2 & 18 & 24,333 & 3,9162 & & \\
\hline \multirow{2}{*}{ indeks telesne mase } & 1 & 15 & 16,2613 & 2,27185 & \multirow{2}{*}{, 722} & \multirow{2}{*}{,476 } \\
\hline & 2 & 18 & 15,8000 & 1,35733 & & \\
\hline \multirow{2}{*}{ veličina kifoze } & 1 & 15 & 38,53 & 24,704 & \multirow{2}{*}{, 514} & \multirow{2}{*}{,611 } \\
\hline & 2 & 18 & 34,28 & 22,798 & & \\
\hline \multirow{2}{*}{ kožni nabor nadlaktice } & 1 & 15 & 9,60 & 4,718 & \multirow{2}{*}{,348 } & \multirow{2}{*}{, 730} \\
\hline & 2 & 18 & 9,10 & 3,530 & & \\
\hline \multirow{2}{*}{ kožni nabor lopatice } & 1 & 15 & 6,67 & 5,802 & \multirow{2}{*}{, 776} & \multirow{2}{*}{,444 } \\
\hline & 2 & 18 & 5,56 & 1,688 & & \\
\hline \multirow{2}{*}{ kožni nabor trbuha } & 1 & 15 & 5,60 & 3,582 & \multirow{2}{*}{,- 412} & \multirow{2}{*}{,683 } \\
\hline & 2 & 18 & 6,06 & 2,775 & & \\
\hline \multirow{2}{*}{ 20m trčanje } & 1 & 12 & 57,75 & 16,869 & \multirow{2}{*}{2,622} & \multirow{2}{*}{,014 } \\
\hline & 2 & 18 & 46,72 & 5,062 & & \\
\hline & 1 & 15 & 348,67 & 123,551 & & \\
\hline staza sa preponama natraśke & 2 & 18 & 241,11 & 70,316 & 3,139 &, 004 \\
\hline dodir nloče & 1 & 15 & 15,40 & 4,085 & 3652 & 001 \\
\hline dodir ploce & 2 & 18 & 19,72 & 2,675 & $-3,052$ &, 001 \\
\hline & 1 & 15 & 31,67 & 5,924 & & \\
\hline pretklon trupom sedeci raznozno & 2 & 18 & 39,17 & 5,113 & $-3,905$ &, 000 \\
\hline & 1 & 15 & 110,67 & 33,980 & & \\
\hline skok udalj $1 \mathrm{Z}$ mesta & 2 & 18 & 130,94 & 24,625 & $-1,985$ & ,056 \\
\hline & 1 & 14 & 85,00 & 145,496 & 821 & 418 \\
\hline izdrżaj u zgibu & 2 & 18 & 122,72 & 114,605 &,$- 8<1$ &, 418 \\
\hline & 1 & 14 & 18,36 & 9,966 & & \\
\hline pregib trupom & 2 & 18 & 25,94 & 6,384 & $-2,618$ &, 014 \\
\hline & 1 & 15 & 2,80 &, 561 & & 120 \\
\hline dinamicka ravnoteza & 2 & 18 & 3,00 &, 000 & $-1,518$ &, 139 \\
\hline & 1 & 15 & 145,53 & 65,412 & & \\
\hline stat. ravnoteza sa otvorenım ocıma & 2 & 18 & 192,78 & 30,641 & $-2, / 32$ & ,010 \\
\hline & 1 & 15 & 71,79 & 53,386 & & \\
\hline stat. ravnoteza zatvorenıh ocıju & 2 & 18 & 90,31 & 56,262 &,- 963 &, 343 \\
\hline & 1 & 13 & 291,77 & 71,891 & & \\
\hline trcanje u grupi od osam & 2 & 18 & 225,61 & 31,035 & 3,115 &, 007 \\
\hline klizaiući koralk & 1 & 15 & 214,13 & 70,391 & 3368 & \\
\hline klizajuci korak & 2 & 18 & 155,83 & 19,728 & 3,368 &, 002 \\
\hline baconio i hyotanis lontt & 1 & 15 & 3,13 & 2,167 & 035 & 357 \\
\hline bacanje 1 hvatanje lopte & 2 & 18 & 3,83 & 2,121 &,- 935 & /55, \\
\hline & 1 & 15 & 2,13 & 1,885 & & \\
\hline vodenje lopte u mestu & 2 & 18 & 3,78 & 2,211 & $-2,2 / 2$ &, 030 \\
\hline
\end{tabular}

$\mathrm{N}$ - brojno stanje; t-test; $\mathrm{p}$ - nivo signifikacije $(\mathrm{p}<0,05)$. 
nim životnim uslovima. Pošto razvijenost ovih sposobnosti određuje uspešan učinak učenika u motoričkim aktivnostima, jedva da se može očekivati da se, u nedostatku doživljaja uspeha, deca u nepovoljnim životnim uslovima rado uključe u sportske aktivnosti u školi, odnosno izvan škole. A kao posledica nastale pasivnosti u potpunosti isključuju sebe iz društvenih zbivanja nastalih na osnovu sportskih i pokretnih aktivnosti. I u pogledu razvijenosti koordinacijskih sposobnosti (ravnoteža, brzo prepoznavanje situacije, koordinacija, osećaj za ritam) važnih za uspešno napredovanje u učenju, u slučaju učenika u nepovoljnim životnim uslovima, takođe primećujemo zaostajanje. Faktorskom analizom (Varimax rotacija) pošlo nam je za rukom da kod učenika prvog razreda izdvojimo pet faktora koji imaju uticaja na pojedine, DIFER testom izmerene, oblasti. To smo konstatovali regresivnom analizom.

Kod učenika prvog razreda dobili smo pet odvojenih faktora. U ovoj starosnoj grupi koordinacija sačinjava najvažniji faktor (pisanje, $\mathrm{p}=\mathbf{0 , 6 3 8}$; slušanje govora, $\mathrm{p}=\mathbf{0 , 4 1 9}$; brojanje $\mathbf{0 , 3 7 7}$; socijalan, $\mathrm{p}=\mathbf{0 , 4 8 8}$ ). Drugi i treći faktor ne sadrže uočljivu signifikantnost sa oblastima izmerenim pomoću DIFER testa. U četvrtom faktoru (ravnoteža) pisanje $\mathrm{p}=\mathbf{0 , 4 0 5}$ i slušanje govora $\mathrm{p}=\mathbf{0 , 4 3 1}$ zastupljeni su sa faktorskom težinom. Peti faktor (kifoza) ne upućuje na povezanosti.
$\mathrm{Na}$ osnovu skromnog uzorka našeg istraživanja ustanovili smo da su učenici prvog razreda u Horgošu iz socijalno osetljivih porodica pokazali znatno zaostajanje na polju svoje motoričke razvijenosti u poređenju sa svojim školskim drugovima koji pripadaju većinskoj kategoriji. Značaj naših rezultata u pobuđivanju pažnje ističe konstatacija da je kretanje osnova svake aktivnosti učenja višeg reda. Kretanje je neizostavno važno za učenje govora, čitanja i pisanja. Razvijanje kretanja ima mnogo parcijalnih oblasti. Tu spada razvijanje svesti o telu, poboljšavanje dodira, opažanja kretanja, osećaja ravnoteže, usklađivanja kretanja dva dela tela, koordinacije osnovnih pokreta, razvijanje prostorne orijentacije, vežbe jačanja poverenja.

Zbog načina života oskudnog u nadražajima, te provođenja manje godina u zabavištu sve je aktuelnija važnost razvijanja motoričkih sposobnosti ukoliko bismo želeli da izbegnemo, u njihovom slučaju, zaostajanje u učenju, koje se protekom godina javlja sve markantnije. Smetnje u motoričkim uvežbanostima utiču u velikoj meri na svakodnevne postupke i na školske učinke, zato ni u zabavištu ni u školi ne sme da bude zanemarena činjenica da u svim stadijumima cirkularnog procesa zapažanja mogu da nastupe smetnje, koje posle mogu da dovedu do pogrešnih reakcija. Mnogi učenici koji žive u nepovoljnim životnim uslovima nisu u stanju da odgovore očekivanjima; na mogućnost takvog zaključ-

Tabela 2. Rezultat analize regresije po faktorima.

\begin{tabular}{|c|c|c|c|c|c|}
\hline & $\begin{array}{c}\text { Motorika, } \\
\text { koordinacija }\end{array}$ & Kožni nabor & Antropometrija & Ravnoteža & Kifoza \\
\hline & \multicolumn{5}{|c|}{ Beta } \\
\hline razred & $\mathbf{0 , 6 3 8}$ & 0,001 & 0,123 & $\mathbf{0 , 4 0 5}$ & 0,143 \\
\hline Pisanje & $\mathbf{0 , 4 1 9}$ & $-0,126$ & 0,196 & $\mathbf{0 , 4 3 1}$ & 0,252 \\
\hline Fonšanje govornog zvuka & 0,255 & $-0,264$ & 0,225 & 0,188 & 0,232 \\
\hline Brolacionih reči & $\mathbf{0 , 3 7 7}$ & $-0,160$ & $-0,019$ & 0,292 & 0,326 \\
\hline Praćenje teksta & 0,322 & $-0,101$ & $-0,111$ & 0,040 & 0,205 \\
\hline Razumevanje povezanosti & 0,297 & $-0,159$ & 0,065 & 0,233 & 0,098 \\
\hline Socijalan & $\mathbf{0 , 4 8 8}$ & $-0,075$ & 0,010 & 0,316 & 0,203 \\
\hline
\end{tabular}

Napomena: Beta-standardizovani regresioni koeficijent. Kod istaknutih vrednosti postoji veza između zavisnih i nezavisnih varijabli (nivo signifikacije $\mathrm{p}<0,05$ ). 
ka navode pokazatelji naših merenja, jer su se kod njih pojavile teškoće u pogledu određenih parcijalnih sposobnosti (percepcija, kognicija, govor, motoričke funkcije).

\section{Zaključak}

Na osnovu rezultata našeg istraživanja skrenuli smo pažnju na značaj fizičkog vaspitanja i kretnih aktivnosti odgovarajuće učestalosti $i$ adekvatnog sadržaja. Moguće je dokazati da razvijenost motoričkih sposobnosti doprinosi i razvijenosti osnovnih kompetencija neophodnih za školsko učenje, kao i socijalnih kompetencija. Razvijenost, tj. razvijanje motoričkih sposobnosti može da bude od posebne važnosti za decu nižeg socijalnog statusa, kako u zabavišnoj životnoj dobi, tako u početnom stadijumu učenja u školi. Smatramo da je važan zadatak da tokom motoričkog razvoja nađemo one mogućnosti pomoću kojih se delotvorno mogu razvijati kompetencije i sposobnosti koje konstituišu implicitni nivoi motoričkih sposobnosti već u zabavištu i u početnoj fazi učenja u školi.

U onim zabavištima u kojim se u većem broju podučavaju deca nepovoljnog položaja i niskog socijalnog statusa vredi realizovati jedan jednostavan način razvijanja sposobnosti. Program razvijanja, koji ne iziskuje mnogo vremena, a doprinosi uobičajenim metodama razvijanja kompetencija, može da pruži dodatnu pomoć u pripremi dece nižeg socijalnog statusa za učenje u školi.
Razvijanje motoričkih sposobnosti može da znači dopunsku, alternativnu mogućnost razvijanja osnovnih kompetencija, a za decu mogućnost koja nudi uživanje i nove sadržaje. Poslednjih decenija školsko obrazovanje sve manje računa sa mogućnostima pruženim motoričkim razvojem u okvirima fiskulture. Suprotno zabavištu, u osnovnoj školi se već mora ravnati prema nastavnom programu, odstupanje od njega je sve teže ostvarljivo. Međutim, u onim regionima sa nepovoljnijim ekonomskim statusom, gde u školama postoji značajan broj učenika nižeg socijalnog statusa čiji roditelji imaju nisku školsku spremu, izričito vredi da se na dnevnom nivou određeni deo školskih aktivnosti posveti razvijanju motoričkih sposobnosti. To vreme može da iznosi svega nekoliko minuta redovno uvedenih sredinom školskih časova, a za koje mogu da se razvijaju ne samo motoričke sposobnosti nego će i deca, osvežena motoričkim aktivnostima, nastaviti učenje s većom pažnjom. Oslanjajući se na rezultate, želimo da sastavimo takvu građu kretanja koja odstupa od dosadašnjeg i odražava novo usmerenje u razvijanju zdravlja. Kvalitetnim fizičkim vaspitanjem razvijamo kod dece moralne, voljne osobine i praktične kompetencije i pripremamo ih za zdrav način života, te za uspešno pozicioniranje u svetu rada. Zahvaljujući pozitivnim doživljajima stečenim tokom kretanja, otvara se mogućnost reprodukovanja telesnih, duhovnih, emotivnih energija. Ne možemo da zanemarimo da je u porodicama lošeg materijalnog statusa dete, $u$ nedostatku roditeljske podrške, upućeno na sebe, te se tako školi, a posebno učitelju, nameće težak zadatak.

\section{Literatura}

- American Federation of Teachers (2004). Waiting Rarely Works: „Late Bloomers“Usually Just Wilt. Washington, DC: American Educator.

- Annett, J. (1995). On knowing how to do things: a theory of motor imagery. Cognitive Brain Research. 3 (1996), 65-69.

- Balogh, L. \& Tóth, L. (1998). Fejezetek a pedagógiai pszichológia köréből II. Tanulmánygyüjtemény (351). Debrecen: KLTE. 
- Benő, Cs. (2001). A kognitív képességek szerepe a tudás szervezésében. In: Báthory, Z. \& Falus, I. (szerk.). Tanulmányok a neveléstudomány köréből (270-293). Budapest: Osiris Kiadó.

- Borkovits, M. (2013). Szocálisan hátrányos helyzetü gyermekek testnevelési telyesitményének vizsgálata. Iskolakultúra. 23 (1), 3-9.

- Brooks-Gunn, J. (2003). Do You Believe In Magic? What We Can Expect From Early Childhood Intervention Programs. Social Policy Report. 17 (1), 8-11.

- Caroll, W. R. \& Bandura, A. (1982). The role of visual monitoring in observational learning of action patterns: making the unobservable observable. Journal of Motor Behavior. 14, 153-167.

- Carroll, W. R. \& Bandura, A. (1987). Translating cognition into action: The role of visual guidance in observational learning. Journal of Motor Behavior. 3, 385-398.

- Central Office of Statistics (2005). Statisztikai Tájékoztató. Borsod-Abaúj-Zemplén, Heves, Nógrád, 2005/4. Central Office of Statistics. Retrieved on November, 2006. from: www.ksh.hu.

- Egressy, J. (2005). Társadalmi esélyegyenlötlenség a versenysportban az úszás példája (doctoral dissertation). Budapest: Semmelweis Egyetem, társadalomtudományi Intézet, Testnevelési és Sporttudományi Kar.

- Fitts, P. M. (1964). Perceptual motor skill learning. In: Melton, A. W. (ed.). Categories of human learning (244-284). New York: Academic Press.

- Frostig, M. \& Horne, D. (1964). The Frostig Program for the development of Visual Perception. Chicago: Follett Publishing, Co.

- Gardner, H. (1983). Frames of mind. Basic Books, A Division of Harper Collins Publishers.

- Gyarmathy, É. \& Telegdi, Á. (1995). Ceruzaforgató. Segédanyag a tanulási zavarok azonositásához és megelözéséhez. Budapest: MTA Pszichológiai Intézete.

- Hallahan, D. P. \& Cruickshank, W. M. (1973). Psychoeducational foundations of learning disabilities. Englewood Cliffs, NJ, Prentice Hall.

- Hart, B. \& Risley, T. (1995). Meaningful Differences in the Everyday Experience of Young American Children. Baltimore: Brookes.

- Heckman, J. J. (2006a). Catchem Young. New York: Wall Street Journal.

- Heckman, J. J. (2006b). Investing in Disadvantaged Young Children Is An Economically Efficient Policy. New York: Committee for Economic Development, Pew Charitable Trusts.

- James, W. (1890). The principles of psychology 1. New York: Henry Holt and Company.

- Józsa, K. (2007). Az elsajátitási motiváció. Budapest: Műszaki Kiadó.

- Keogh, J. \& Sugden, D. (1985). Movement skill development. New York: McMillan.

- Kephart, N. C. \& Roach, E. G. (1966). The Purdue Perceptual - Motor Survey. Columbus, Ohio: Merrill Books Inc.

- Kertesi, G. \& Kézdi, G. (1998). A cigány népesség Magyarországon (dokumentáció és (adattár). Budapest: Sociotypo Könyvkiadó.

- Király, T. \& Szakály, Zs. (2011). Mozgásfejlődés és a motorikus képességek fejlesztése gyermekkorban. Budapest: Dialóg Campus Kiadó. 
- Kirk, S. A. \& Bateman, B. (1962). Diagnosis and remediation of learning disabilities. Exceptional Children. 29, 73-78.

- Krombholz, H. (1997). Physical performance in relation to age, sex, social class, and sports activities in kindergarten and elementary school. Perceptual and Motor Skills. 84, 1168-1170.

- Krombholz, H. (2003). Motorische Kompetenzen. Bayerisches Staatsministerium für Arbeit und Sozialordnung, Familie und Frauen \& IFP (Hrsg.). München: Was Horte Schulkindern zu bieten haben.

- Lee, V. \& Burkam, D. (2002). Inequality at the Starting Gate. Gate: Social Background Differences in Achievement as Children Begin School. Washington, DC: Economic Policy Institute.

- Lepeš, J., Ivanović, J. (2012). Interkulturalno obrazovanje učitelja kao preduvjet uspješnog obrazovanja romske djece. U: Posavec, K. \& Sablić, M. (ur.). Pedagogija i kultura - svezak 3. - Znanstvena monografija - Interkulturalna pedagogija: prema novim razvojima znanosti o odgoju (208-221). Zagreb: Hrvatsko pedagogijsko društvo.

- Lepeš, J., Halaši, S. \& Ivanović, J. (2016). Motor abilities and school readiness at disadvantaged children. Croation Journal of Education. 32-42 (in print).

- Makszin, I. (1994). Az oktatás és tanulás folyamata. In: Báthori, B. (szerk.). A testnevelés elmélete és módszertana (87-127). Budapest: Magyar Testnevelési Egyetem.

- Malina, R. M. (1980). Biosocial correlation of motor development during infancy and childhood. New York: Academic Press.

- Marton Dévényi, É., Jordanidisz, Á. \& Horváth, I. (2007). Gondolatok a diszlexia végsö okairól. Az Alapozó Terápia hatása. Esettanulmányok. Budapest: Alapozó Terápiák Alapítvány.

- Mészáros, J., Mészáros, Zs., Zsidegh, M., Prókai, A., Vajda, I., Photiou, A. \& Mohácsi, J. (2006a). Nemzedékenkénti növekedési különbségek és utánpótlás-nevelés. Magyar Sporttudományi Szemle. 7, 3-6.

- Mészáros, J., Mohácsi, J., Frenkl, R., Szabó, T. \& Szmodis, I. (1986). Age dependency in the development of motor test performance. In: Rutenfranz, J., Mocellin, R. \& Klimt, F. (eds.). Children and Exercise XII Illinois (347-353). Chapaign: Human Kinetics.

- Mészáros, Zs., Vajda, I., Mészáros, J., Photiou, A. \& Zsidegh, M. (2006b). Leányok testösszetételés motorikus teljesítményváltozása. Sportorvosi Szemle. 47, 62.

- Mészáros, Zs., Kiss, K., Szmodis, M. B., Zsidegh, M., Mavroudes, M. \& Mészáros, J. (2009). Effects of attending elevated level school physical education in 7-to-11-year-old boys. Acta Physiologica Hungarica. 96, 349-357.

- Nagy, G. (1972). A cselekvéstanulás néhány pszichológiai és ezzel öszefüggő módszertani problémája. In: Nagy, G. (szerk.). A testnevelés néhány tantárgypedagógiai problémája (185-213). Budapest: Országos Pedagógiai Intézet.

- Nagy, J. (1980). 5-6 éves gyermekeink iskolakészültsége. Budapest: Akadémiai Kiadó.

- Nagy, J., Józsa, K., Vidákovich, T. \& Fazekasné Fenyvesi, M. (2004b). Az elemi alapkészségek fejlödése 4-8 éves életkorban. Szeged: Mozaik Kiadó.

- Parízková, J. (1961). Total body fat and skinfold thickness in children. Metabolism. 10, 794-807. 
- Photiou, A., Anning, J. H., Mészáros, J., Vajda, I., Mészáros, Z., Sziva, Á., Prókai, A. \& Ng, N. (2008). Lifestyle, Body Composition, and Physical Fitness Changes in Hungarian School Boys (1975-2005). Research Quarterly for Exercise and Sport. 79, 168-173.

- Porkolábné Balogh, K. (1992). Kudarc nélkül az iskolába. Budapest: Alex-Typo.

- Rókusfalvy, P. (1980). A sporttevékenység regulácios felfogása. A telyesitmény motivációés a döntés kisérleti vizsgálata a sporttevékenységben. Budapest: Akadémiai Kiadó.

- Rolnick, A. \& Grunewald, R. (2003). Early Childhood Development: Economic Development with High Public Return.

- Sziva, Á., Mészáros, Zs., Kiss, K., Mavroudes, M., Ng, N. \& Mészáros, J. (2009). Longitudinal differences, in running endurance and body mass index - a 25-year comparison. Acta Physiologica Hungarica. 96, 359-368.

- Tatár, A., Zsidegh, M., Mészáros, Zs., Ihász, F., Prókai, A., Vajda, I. \& Mészáros, J. (2003). Physique, body composition and motor performance in Hungarian and Roma boys. Revista Portuguesa de Ciéncias do Desporto. 3, 122-124.

- Vuilemin, A., Boini, S., Bertrais, S., Tessier. S., Oppert, J. M., Hercberg, S., Guilemin, F. \& Briancon, S. (2005). Leisure time physical activity and health-related quality of life. Preventive Medicine. 41 (2), 562-9.

\begin{abstract}
Summary
The aim of the study presented in this paper was to determine the relationship between disadvantaged children's academic performance and development of their motor skills. First-graders were in the focus of this research, the aim of which was to shed light on the unequal opportunities that children have from the very first day of primary school. The differences in the level of physical development and motor performance between disadvantaged children and other children were compared and analysed. The aim of the research was also to determine, if statistically significant differences were identified, how much the disadvantaged children lagged behind the majority children. Data collection was performed among 15 first-graders attending a primary school in Horgoš who were categorised as disadvantaged by the school psychologist and the pedagogue. The control group measurement was conducted on 18 randomly selected first-graders who were not categorised as disadvantaged. Based on the research results, the quality of physical education, its frequency and adequate content prove to be of high importance for the disadvantaged children. It can be concluded that the development of motor skills contributes not only to the optimal development of basic competences needed for a successful performance at school, but also to the development of the social competences.
\end{abstract}

Keywords: motor skills, living conditions, physical development, physical education, learning. 